\title{
Determinants of Financial Statement Fraud Using the Fraud Hexagon Model
}

\author{
Anak Agung Istri Pranyanita I Dewa Gde Dharma Suputra I Dewa Nyoman Badera \\ Maria Mediatrix Ratna Sari \\ Faculty of Economics and Business, Udayana University, Bali, Indonesia
}

\begin{abstract}
This study aims to obtain empirical evidence about the fraud hexagon theory. The research was conducted on manufacturing companies in the consumer goods industry sector listed on the Indonesia Stock Exchange (IDX) for the 2015-2019 period. The sampling method used was non-probability sampling with purposive sampling technique. There are 42 companies as a population with a total of 35 companies as a sample. The data analysis technique used is multiple linear regression. Based on the results of the analysis, it is stated that financial stability and rationalization have a positive effect on indications of financial statement fraud, while ineffective monitoring, CEO education, political connectivity, and CEO duality have no effect on indications of financial statement fraud. The research has implications for the government as a regulator, or for those who use information in financial statements as a consideration in assessing the opportunities for fraudulent actions to occur on the company's financial statements.
\end{abstract}

Keywords: financial statement fraud, fraud hexagon, financial stability, ineffective monitoring, CEO education, rationalization, political connectivity, CEO duality

DOI: $10.7176 /$ RJFA/12-23-03

Publication date: December $31^{\text {st }} 2021$

\section{Introduction}

According to the Association of Certified Fraud Examiners (ACFE), fraud is an intentional act that violates the law by manipulating and presenting false reports to other parties for personal or group gain. The Asia-Pacific Association of Certified Fraud Examiners (ACFE) survey in 2018 stated that there were three main categories of fraud, namely asset misappropriations, corruption, and financial statement fraud. Based on the ACFE survey, cases of financial statement fraud (financial statement fraud) are the fewest cases, which are $13 \%$ compared to asset misappropriation and corruption, but financial statement fraud causes the largest loss with an average loss US\$ 700,000.

On the other hand, a survey conducted by the ACFE Chapter Indonesia in 2016 with primary data on the method of filling out questionnaires to members of the ACFE Chapter Indonesia and secondary data on corruptors in Indonesia obtained from the Supreme Court's website at the Directory of Corruption Crimes Decisions. Financial statement fraud cases are the fewest cases in Indonesia, with a value of $2 \%$ compared to corruption and asset misappropriations.

Although financial statement fraud has a small percentage of $2 \%$, the losses caused by financial statement fraud are quite large with an average loss of over 10 billion rupiah. This small percentage is suspected because in Indonesia there are still many crimes stemming from financial statement fraud that have not been revealed, such as the crime of fraudulent tax information and the stock exchange. Fraudulent financial statements can damage public confidence in the reliability of financial reporting which is a source of information to assess the company's future prospects (Omar et al., 2017). In addition, the fraud committed can also injure the accounting values themselves (Sihombing \& Rahardjo, 2014). Therefore, the role of management, internal auditors and external auditors is needed to prevent and detect the potential for fraudulent financial statements in the company. The role of management in preventing fraudulent financial statements that can be done is by applying correct accounting policies, adequate internal control and implementing good corporate governance.

Based on the 2018 ACFE survey, it shows that the manufacturing sector is the highest sector that commits financial statement fraud, which is $17 \%$ with 38 cases during 2018 . This is proven by the many cases of fraud in the manufacturing sector that have occurred in recent years. The number of cases of financial statement fraud that occurs is one of the auditor's responsibilities in detecting fraud, so that the company's financial statements can be trusted and the company value remains good for users of financial statements.

One of the theories that can be used to detect fraud is the fraud theory that has been developed by various previous researchers. One of the theories of fraud, namely the fraud triangle, was coined by Cressey in 1953 in his research entitled "Other People's Money: A Study in the Social Psychology of Embezzlement". The fraud triangle consists of three fraud detection components, namely pressure, opportunity, and rationalization.

Models in fraud detection have developed. The next development is the fraud diamond, which was coined by Wolfe and Hermason in 2004. The fraud diamond is a development of the fraud triangle theory by adding one component in fraud detection, namely capability. The next theory development is the fraud pentagon by Crowe 
in 2011. The fraud pentagon is a development of the fraud triangle and fraud diamond models with additional components of competence and arrogance. This model was refined by Vousinas in 2017 as the S.C.O.R.E Model with components of stimulus (pressure), capability, opportunity, rationalization, and ego.

The fraud triangle, fraud diamond and fraud pentagon models were further developed into a fraud hexagon by Vousinas in 2017, called the S.C.C.O.R.E Model, with the addition of a collusion component. Measurement of the fraud component cannot be studied directly, therefore a proxy is needed to measure this component. The proxies used to measure each component of the fraud hexagon in this study include pressure as proxied by financial stability, opportunity as proxied by ineffective monitoring, capability as proxied by CEO education, rationalization, collusion as proxied by political connectivity, and ego as proxied by CEO duality. Research on the factors that influence financial statement fraud has been carried out by several previous researchers and is inconsistent, including research conducted by Lestari \& Henny (2019) regarding the effect of pentagon fraud on financial statement fraud in banking companies. The variables used are financial targets, financial stability, ineffective supervision, auditor turnover, CEO education, frequency of CEO photos. The results of this study indicate that the variables of financial stability and ineffectiveness of supervision affect financial statement fraud, while the financial target variables, auditor turnover, CEO education, and CEO picture frequency have no effect on financial statement fraud. Meanwhile, Agusputri \& Sofie (2019) stated that financial stability had no effect on fraudulent financial statements. A study conducted by Pujiastuti (2018) regarding the effect of triangle fraud on financial statement fraud in manufacturing companies listed on the Indonesia Stock Exchange for the period 2012-2016.

The results of this study indicate that personal financial need with OSHIP proxy, nature of industry with RPT proxy, ineffective monitoring with IND proxy, and auditor switch with AUD proxy do not have a significant effect on fraud assessed through financial statements. Meanwhile, financial stability with TA proxies, external pressure with LEV proxies and financial targets with ROA proxies resulted in a significant effect on fraud in financial statements with earnings management proxies. The results of Yuliastini and Suardikha's research (2019) state that opportunity and rationalization have proven to be the diamond elements of fraud that most influence the occurrence of fraudulent financial reporting in companies. Meanwhile, pressure and capability have no effect on fraudulent financial reporting.

\section{Literature Review and Hypotheses Development}

The stability of the company's financial condition can be seen from the assets owned because assets show the wealth of the company (Rahmawati et al., 2017). Fraud can arise when the company's management is under pressure to show that the company has been able to manage its assets well. Percentage change in total assets indicating fraud in financial statements, because a high percentage change in total assets as a way to show earnings strength of the company and a stronger financial position (Indriani \& Terzaghi, 2017). Research conducted by Skousen et al., (2009) proves that the greater the ratio of changes in the total assets of a company, the probability of committing fraudulent actions on the company's financial statements is higher.

Research by Apriliana \& Agustina (2017) measures financial stability using the ratio of changes in total assets and proves that companies with high changes in total assets have the potential to commit financial statement fraud to attract investors' attention. The results of this study are supported by the results of research conducted by Faradiza (2019) which shows that the higher the ratio of changes in total assets, the higher the risk of financial statement fraud that may be carried out by the company. Based on the description above, it is suspected that the higher the ratio of changes in total assets, the higher the possibility of companies committing fraudulent financial statements. Research conducted by Skousen et al., (2009) proves that the greater the ratio of changes in the total assets of a company, the probability of committing fraud in the company's financial statements is higher. In addition, Martyanta's research (2013) proves that financial stability proxied by changes in assets has an effect on fraudulent financial statements.

H1: Financial stability has a positive effect on fraudulent financial statements.

Ineffective monitoring has a relationship with agency theory which explains that the principal gives authority to the agent to carry out the interests of the principal, but the agent in managing the company tends to prioritize his personal interests. This difference in interests causes the principal to supervise the agent, because if the supervision of the company is not effective, it will provide an opportunity for the agent to commit fraud. Attribution theory is also related to ineffective monitoring, where attribution theory explains how we consider things differently, depending on the meaning or meanings we attribute to certain behaviors. When we observe individual behavior, we try to consider whether it is caused by internal or external factors. Pujiastuti's research (2018) on the effect of triangle fraud on financial statement fraud in manufacturing companies listed on the Indonesia Stock Exchange for the period 2012-2016. The results of this study state that ineffective monitoring with the IND proxy does not have a significant effect on fraud assessed through financial statements.

Martantya \& Daljono (2013) state that the high level of fraud that occurs in Indonesia is one of the causes of low supervision so that it creates a gap for someone to commit fraud. fraud. So it is presumed that the higher 
the ineffectiveness of supervision, the weaker the internal control over management performance, so that the possibility of fraudulent financial statements will be higher. This statement is in accordance with research by Sulkiyah (2016), and Agusputri \& Sofie (2019).

H2: Ineffective monitoring has a positive effect on financial statement fraud.

Report to The Nations 2018 by the Association Of Certified Fraud Examiners (ACFE) which states that most fraud perpetrators are committed by someone with a minimum education degree. Although most fraud perpetrators are carried out by someone with a bachelor's level of education, the most losses from financial statement fraud are carried out by someone with the lowest education of Masters (Strata two). Cases of financial statement fraud can be caused by managerial factors, one of which is the CEO's educational background (Troy, 2003).

Soselisa \& Mukhlasin (2008) also argue that Masters education increases self-interested behavior that can cause harm to other parties. This condition expands the potential for fraud that can be carried out by the CEO. Troy (2003) and Ying \& Yeung (2014) state that the higher the education taken by the CEO, the higher the possibility of fraudulent financial statements carried out with the aim of taking advantage for themselves. Sophie (2019).

H3: CEO education has a positive effect on financial statement fraud.

The frequency of auditor turnover usually indicates that the company is committing fraud, the change of auditors is carried out so that financial statement fraud committed by the company is not detected by the change of auditors. Lou and Wang (2009) state that the possibility of detecting fraudulent financial statements can be reduced by the change of auditors, the change of auditors in a company will reduce the possibility of detecting fraudulent financial statements by the auditors. Modifications by agents are carried out due to differences in interests between agents and principals, where agents try to present financial statements as well as possible so that the company's performance is considered good and can influence the assessment of decision making. Theories related to rationalization are agency theory and attribution theory.

Fraud in the form of manipulation by management is carried out so that the performance of the company looks good. So, it can be presumed that the more often the company changes the auditor, the greater the possibility of fraudulent financial reporting. Rationalization can also be one of the causes of fraudulent financial statements. Rationalization is the existence of ethical attitudes or values which are justifications for a person, so that he feels innocent when he commits fraud (Amaliah, 2015). However, this is contrary to the results of Firdausi's (2021) research which shows that rationalization has no significant effect on financial statement fraud.

H4: Rationalization has a positive effect on financial statement fraud.

The manipulation is related to the different goals of the agent and the principal, where the agent wants their own welfare to get the maximum benefit from their performance, this is in line with agency theory. With the help of resources from politicians, agents can use them to commit fraud. This is also related to adverse selection, namely the existence of information that is known by management and is not conveyed to the principal.

Research by Faccio et al. (2006) stated that companies with political connections have lower performance than companies without political connections. However, the more loans the company receives, the more difficult it is for the company to pay its debts and this can lead to financial distress. Financial distress can have a negative effect on the company where it becomes a pressure to commit fraudulent practices with the aim of showing good company performance and covering up the company's bad things in the eyes of investors. Therefore, it is suspected that companies with political connections have a greater potential for fraudulent financial statements. This statement is in line with previous research conducted by Matangkin et al. (2018), Ding et al. (2014), and Fan et al. (2007).

H5: Political Connectivity has a positive effect on financial statement fraud.

According to Yang et al. (2017), CEO duality causes bad corporate governance. This is because the CEO cannot perform a supervisory function that is separate from his personal interests. This will cause the value of the company to decrease, so there is a need for a separation of duties so that the supervisory function in the company can run more optimally. CEO duality also causes the CEO to have dominance of power and reduces the independence of the directors (Sasongko \& Wijayantika, 2019).

OJK Regulation Number 55/POJK.03/2016 which states that the board of directors is prohibited from holding concurrent positions as the board of commissioners. Therefore, CEO duality in Indonesia uses a kinship system in the placement of the board of directors and the board of commissioners, where there is still a family relationship (Ratnasari \& Solikhah, 2019).

H6: CEO duality has a positive effect on financial statement fraud.

\section{Methods}

This research was conducted on the official website www.idx.co.id at the Consumer Goods Industrial Sector Manufacturing Companies listed on the Indonesia Stock Exchange. The population in this study are all manufacturing companies in the consumer goods industry sector listed on the Indonesia Stock Exchange which 
publish financial reports for the 2015 to 2019 financial year. Manufacturing companies in the consumer goods industry sector are listed on the Indonesia Stock Exchange. The population is 42 companies, obtained from downloading softcopy of issuer's financial statements on the Indonesia Stock Exchange website www.idx.co.id. The sampling method used in this study was purposive sampling method, namely the collection of sample data not taken at random but the sample was selected based on certain criteria that became the basis for sampling by the researcher. This study uses Partial Least Squares (PLS) analysis which is used to test the effect of the dependent and independent variables.

\section{Results and Discussion}

\section{Partial Least Squares (PLS) Analysis}

Measurement Model Evaluation Results (Outer model)

The outer model or measurement model is to describe a relationship between the indicator block and its latent variables. The design of this measurement model determines the nature of the indicators derived from each latent construct, which is based on the operational definition of the variable. A research concept or model cannot be tested if it is not tested in the relational and causal relationship prediction model. If it has not passed the purification stage in the measurement model, then the measurement model is used, namely validity and reliability tests.

Measurement Model Evaluation Results (Inner model)

The structural model in PLS is evaluated by using $\mathrm{R}^{2}$ for the dependent construct, path coefficient values or $\mathrm{t}$ values for each path to test the significance between constructs in the structural model. The value of $\mathrm{R}^{2}$ is used to measure the level of variation of changes in the independent variable to the dependent variable. The higher the $\mathrm{R}^{2}$ value, the better the prediction model of the proposed research model (Jogiyanto and Abdillah 2016). The path coefficient value or the inner model shows a significant level in hypothesis testing. The path coefficient score or inner model, indicated by the T-statitic value, must be above 1.64 for the one-tailed hypothesis for hypothesis testing at 5\% alpha and 80\% power (Hair et al. 2006 in Jogiyanto and Abdillah 2016).

$R$-square

$\mathrm{R}$-square for the dependent construct R-square value can be used to evaluate the effect of predictors on each endogenous latent variable. The results of $\mathrm{R} 2$ of $0.67,0.33$ and 0.19 for endogenous latent variables in the structural model indicate that the model is "good", "moderate", and "weak". The R-square value is used to later calculate the Q-square value which is the goodness of fit model test.

Table 1. R-square test results

\begin{tabular}{lll}
\hline & R Square & R Square Adjusted \\
\hline Financial Report Fraud (Y)_ & 0,957 & 0,955 \\
\hline
\end{tabular}

Secondary Data, 2021

Based on Table 1 above, the R-square value for the variables of financial stability, ineffective monitoring, CEO education, rationalization, political connectivity and CEO duality on fraudulent financial statements is 0.957 , including both which shows a large influence of $0.957 \times 100 \%=95.7 \%$.

Q-square

The inner model test is done by looking at the Q-square value which is the goodness of fit test of the model. If the Q-square value is greater than 0 (zero) it indicates that the model has predictive relevance, while the Qsquare value is less than 0 (zero) indicating that the model lacks predictive relevance. However, if the calculation results show the Q-square value is more than 0 (zero), then the model is feasible to be said to have a relevant predictive value. Q-square calculation can be seen as follows:

$\mathrm{Q} 2=1-\left(1-\mathrm{R} 1^{2}\right)$

$\mathrm{Q} 2=1-(1-0.957)$

$\mathrm{Q} 2=1-(0.043)$

$\mathrm{Q} 2=0.957$

Based on the above calculation, the Q-square value of 0.957 is more than 0 , so it can be concluded that the model has a predictive relevance value or the model deserves to be said to have a relevant predictive value.

Hypothesis test

Hypothesis testing is the process of evaluating the null hypothesis, where the hypothesis can be accepted or rejected. The opposite of the null hypothesis is the alternative hypothesis which states that there is a difference between the parameter and the statistic. Testing this hypothesis can be done by looking at the value of the $\mathrm{t}$ statistic which uses a significance level of $95 \%(=0.05$ or $5 \%)$. Meanwhile, the t-table value with a significance level of $95 \%$ is 1.96 . The criteria for rejection and acceptance of the hypothesis are that Ha is accepted and Ho is rejected if the t-statistic $>1.96$ and vice versa. 
Table 2. Direct Effect Results

\begin{tabular}{|c|c|c|c|c|c|}
\hline & $\begin{array}{l}\text { Original } \\
\text { Sample }(O)\end{array}$ & $\begin{array}{l}\text { Sample } \\
\text { Mean (M) }\end{array}$ & $\begin{array}{l}\text { Standard } \\
\text { Deviation } \\
\text { (STDEV) }\end{array}$ & $\begin{array}{l}\mathrm{T} \\
\text { Statistics } \\
(\mid \mathrm{O} / \mathrm{STDE} \\
\mathrm{V} \mid)\end{array}$ & P Values \\
\hline $\begin{array}{ccc}\text { CEO Duality (X6) } & -> & \text { Fraudulent } \\
\text { Financial Report (Y) }\end{array}$ & 2,469 & 1,585 & 1,534 & 1,610 & 0,110 \\
\hline $\begin{array}{l}\text { Financial stability }(\mathrm{X} 1)_{-}->\text {Fraudulent } \\
\text { Financial Report }(\mathrm{Y})_{-}\end{array}$ & 0,346 & 0,427 & 0,125 & 2,768 & 0,006 \\
\hline $\begin{array}{lccc}\text { Ineffective } & \text { monitoring }(\mathrm{X} 2)_{-} & -> \\
\text {Fraudulent_Financial Report }(\mathrm{Y})_{-} & \end{array}$ & 0,071 & 0,091 & 0,422 & 0,168 & 0,867 \\
\hline $\begin{array}{llll}\text { Political } & \text { Connectivity }(\mathrm{X} 5) & -> \\
\text { Fraudulent_Financial Report }(\mathrm{Y}) & \end{array}$ & $-0,022$ & $-0,016$ & 0,035 & 0,617 & 0,538 \\
\hline $\begin{array}{l}\text { CEO Education (X3) } \\
\text { Report Fraud }(Y)_{-}\end{array}$ & $-1,547$ & $-0,930$ & 1,324 & 1,168 & 0,245 \\
\hline $\begin{array}{lll}\text { Rationalization (X4) } & -> & \text { Fraudulent } \\
\text { Financial Report }(\mathrm{Y}) & & \\
\end{array}$ & 0,263 & 0,215 & 0,113 & 2,316 & 0,022 \\
\hline
\end{tabular}

Secondary Data, 2021

The Effect of Financial Stability on Fraudulent Financial Statements

Based on the results of data analysis, it was found that the p-value of the financial stability variable against financial statement fraud was 0.006 which was compared to a significant value of 0.05 . Because the p-value $<$ significant $(0.006<0.05)$ with a positive beta value of 0.346 and a t-statistic value of 2.768 compared to a t-table of 1.96 . Because the value of t-statistics $>t$-value $(2.768>1.96)$, it can be concluded that financial stability has a positive effect on financial statement fraud. This means that the more stable a company's finances are, the higher the potential that the company will commit fraudulent financial statements. Conversely, the lower the level of financial stability of a company, the lower the potential for companies to commit financial statement fraud.

Based on testing the first hypothesis is accepted, this means that financial stability has an effect on fraudulent financial statements. The stability of the company's financial condition can be seen from the assets owned because assets show the wealth owned by the company (Rahmawati et al., 2017). Fraud can arise when the company's management is under pressure to show that the company has been able to manage its assets well. Percentage change in total assets indicating fraud in financial statements, because a high percentage change in total assets as a way to show earnings strength of the company and a stronger financial position (Indriani \& Terzaghi, 2017).

The results of this study are in line with the fraud hexagon theory which states that the pressure proxied by financial stability has an effect on fraudulent financial statements. That the greater the total assets of a company, the higher the indication of fraudulent financial statements committed by the company. Thus, agency theory and motivation theory are able to explain a significant relationship between financial stability and financial statement fraud.

The results of this study are in line with research conducted by Skousen et al., (2009) proving that the greater the ratio of changes in the total assets of a company, the probability of committing fraudulent actions on the company's financial statements is higher. Apriliana \& Agustina (2017) measure financial stability using the ratio of changes in total assets and prove that companies with high changes in total assets have the potential to commit fraudulent financial statements to attract investors' attention. Faradiza (2019) which shows that the higher the ratio of changes in total assets, the higher the risk of financial statement fraud that may be carried out by the company.

The Effect of Ineffective monitoring on Fraudulent Financial Statements

Based on the results of data analysis, the p-value of the ineffective monitoring variable for financial statement fraud was 0.867 which was compared to a significant value of 0.05 . Because the $p$-value is $>$ significant $(0.867>$ 0.05 ) with a positive beta value of 0.071 and a t-statistic value of 0.168 which is compared to a t-table of 1.96 . Because the $\mathrm{t}$-statistical value $<\mathrm{t}$-value $(0.168<1.96)$ it can be concluded that ineffective monitoring has no effect on financial statement fraud. This means that ineffective monitoring does not affect fraudulent financial statements.

Based on the results of testing the second hypothesis is rejected, this means that the ineffective monitoring variable has no effect in detecting fraudulent financial statements. In general, the existence of an independent board of commissioners will provide little guarantee of supervision in a company. However, the number or number of independent commissioners does not provide a guarantee to increase the company's operational supervision. This is because if there is intervention on the independent board of commissioners, the supervision within the company will not be objective.

The results of this study are not in line with agency theory, and attribution theory. Agency theory and 
attribution are not able to explain the relationship between ineffective monitoring and financial statement fraud. The results of this study are in line with research conducted by Kurnia \& Anis (2017) with research results showing that ineffective monitoring has no effect on financial statement fraud. Triyanto (2019) which states that ineffective monitoring has no effect on fraudulent financial statements. Pujiastuti (2018) states that ineffective monitoring with the IND proxy does not have a significant effect on fraud assessed through financial statements. The Effect of CEO Education on Financial Statement Fraud

Based on the results of data analysis, the p-value of the CEO education variable on financial statement fraud was 0.245 , which was compared to a significant value of 0.05 . Because the $p$-value $>$ significant $(0.245>0.05)$ with a negative beta value of 1.547 and a t-statistic value of 1.168 compared to a t-table of 1.96 . Because the value of t-statistic $<$ t-value $(1.168<1.96)$ it can be concluded that CEO education has no effect on financial statement fraud. This means that CEO education does not affect the increase or decrease in financial statement fraud.

CEO education is a proxy for the capability variable. Based on the results of hypothesis testing, the third hypothesis is rejected, meaning that CEO education has no effect on financial statement fraud. This is because CEOs who have high education tend to carry out performance development in the company. The ability possessed by the CEO is used to manage company operations and company finances, and there is no tendency to manipulate or commit other financial statements fraud. According to Pardoen (1998) one form of human capital is education. An educated person will be more rational in thinking and acting and understand the duties and responsibilities well. Leaders who have education, knowledge and experience are expected to be able to identify, analyze and take policies correctly in optimizing all opportunities for success (especially financial performance) in the future (Jannah, 2017). Attribution theory and agency theory are unable to explain the relationship between CEO education and financial statement fraud.

The results of this study are in line with research conducted by Triyanto (2019) which states that CEO education has no effect on financial statement fraud. Lestari \& Henny (2019) which states that CEO's education has no effect on fraudulent financial statements.

\section{The Effect of Rationalization on Fraudulent Financial Statements}

Based on the results of data analysis, the p-value of the rationalization variable for financial statement fraud was 0.022 , which was compared to a significant value of 0.05 . Because the p-value $<$ significant $(0.022<0.05)$ with a positive beta value of 0.263 and a t-statistic value of 2.316 compared to a t-table of 1.96 . Because the tstatistical value $>$ t-value $(2.316>1.96)$, it can be concluded that rationalization has a positive effect on financial statement fraud. This means that the more often the company changes auditors, the higher the potential for companies to commit financial statement fraud and vice versa.

Based on hypothesis testing, the fourth hypothesis is accepted, meaning that rationalization has an effect on financial statement fraud. This is because the frequency of auditor turnover usually indicates that the company is committing fraud, the auditor's turnover is carried out so that financial statement fraud by the company is not detected by the change of auditors. Lou and Wang (2009) state that the possibility of detecting fraudulent financial statements can be reduced by the change of auditors, the change of auditors in a company will reduce the possibility of detecting fraudulent financial statements by the auditors. Modifications by agents are carried out due to differences in interests between agents and principals, where agents try to present financial statements as well as possible so that the company's performance is considered good and can influence the assessment of decision making. The results of this study state that agency theory and attribution theory are able to explain the rationalization relationship on financial statement fraud

The results of this study are in line with research conducted by Lou and Wang (2009) that the possibility of detecting fraudulent financial statements can be reduced by the change of auditors, Agusputri \& Sofie (2019) which states that ratinalization affects fraudulent financial reporting.

\section{The Effect of Political Connectivity on Fraudulent Financial Statements}

Based on the results of data analysis, the p-value of the political connectivity variable on financial statement fraud is 0.538 which is compared to a significant value of 0.05 . Because the p-value is $>$ significant $(0.538>$ 0.05 ) with a negative beta value of 0.022 and a t-statistic value of 0.617 which is compared to a t-table of 1.96 . Because the t-statistical value $<$ t-value $(0.617<1.96)$ it can be concluded that political connectivity has no effect on financial statement fraud. This means that political connectivity does not affect financial statement fraud.

Based on hypothesis testing, the fifth hypothesis is rejected, meaning that political connectivity has no effect on fraudulent financial statements. This is because the company's board of commissioners, if they have political connections with the political elite, tends to improve the company's performance. Not to manipulate financial statements to look good. The results of this study are not in line with agency and attribution theory, because agency theory has not been able to explain the relationship of political connectivity to financial statement fraud.

The results of this study are in line with research conducted by Triyanto (2019) which states that political connections have no effect on financial statement fraud. In addition, this study is in line with research conducted 
by Ngan (2013) and Sabrina et al. (2020) which states that political connections have no effect on financial statement fraud.

The Effect of CEO Duality on Financial Statement Fraud

Based on the results of data analysis, the p-value of the CEO duality variable on financial statement fraud was 0.110 which was compared to a significant value of 0.05 . Because the $p$-value $>$ significant $(0.110>0.05)$ with a positive beta value of 2.469 and a t-statistic value of 1.610 compared to a t-table of 1.96. Because the value of $t-$ statistics $<$ t-value $(1.610<1.96)$ it can be concluded that CEO duality has no effect on fraudulent financial statements. This means that CEO duality does not affect financial statement fraud.

Based on hypothesis testing, the sixth hypothesis in this study was rejected, meaning that CEO duality has no effect on financial statement fraud. CEO duality is a proxy for the arrogance variable. The results of this study are not in line with agency theory, because agency theory is unable to explain the relationship between CEO duality and financial statement fraud. This can be caused because CEOs who have more than one position take advantage of their positions to improve company performance and to maintain their own performance in maintaining their position in the company. Another factor is that the role of the board of commissioners and committees has been maximized in supervising the performance of the CEO, so that the CEO cannot abuse his power to commit fraud. The results of this study are in line with the research conducted by Lin et al. (2015), Triyanto (2019), and Ratnasari (2019) which state that CEO duality has no effect on fraudulent financial statements.

\section{Conclusion}

The results of this study contribute that the variable. The results of this study contribute that financial stability and rationalization have a positive effect on indications of financial statements in consumer goods industrial sector companies listed on the Indonesia Stock Exchange for the 2015-2019 period. This indicates that the higher the financial stability as indicated by the higher the total assets, the greater the indication of conducting financial statements. Also with the rationalization that uses a change in auditor proxy which states that the company often changes auditors, the larger the financial statements are carried out. This study provides all shareholders, the government, and other parties who need information as a consideration in providing an incident against the possibility of fraudulent financial statements in the company by considering the factors that influence it. The results of this study can also provide feedback and the management in doing so in the company's financial statements.

\section{References}

Apriliana, S., \& Agustina, L. (2017). The Analysis of Fraudulent Financial Reporting Determinant through Fraud Pentagon Approach. Jurnal Dinamika Akuntansi, 9(2), 154-165. https://doi.org/10.15294/jda.v7i1.4036

Faccio, M., Masulis, R. W., \& Mcconnell, J. J. (2006). Political connections and corporate bailouts. Journal of Finance, 61(6), 2597-2635. https://doi.org/10.1111/j.1540-6261.2006.01000.x

Fan, J. P. H., Wong, T. J., \& Zhang, T. (2007). Politically Connected CEOs, Corporate Governance, and PostIPO Performance of China's Newly partially Privatized Firms. Journal of Financial Economics, 330-357.

Faradiza, S. A. (2018). Fraud Pentagon Dan Kecurangan Laporan Keuangan. EkBis: Jurnal Ekonomi Dan Bisnis, 2(1), 1-22.

Firdaus, A., Triyanto DN. (2021). ANALISIS FRAUD DIAMOND DALAM MENDETEKSI POTENSI KECURANGAN LAPORAN KEUANGAN. Bandung. e-Proceeding of Management : Vol.8, No.4 Agustus 2021

Firdaus, E. F., \& Suryandari, E. (2008). PENGARUH FAKTOR KULTUR ORGANISASI, MANAJEMEN, STRATEGI, KEUANGAN, AUDITOR DAN PEMERINTAHAN TERHADAP KECENDERUNGAN KECURANGAN AKUNTANSI. Jurnal Akuntansi Dan Investasi, 9(2), 173- Fitrawansyah. (2014). Fraud Auditing.

Hou, W., \& Moore, G. (2010). Player and Referee Roles Held Jointly: The Effect of State Ownership on China's Regulatory Enforcement Against Fraud. Journal of Business Ethics, 95(SUPPL. 2), $317-335$. https://doi.org/10.1007/s10551-011-0858-1

Jannah, N. A. (2017). PENGARUH GENDER DAN LATAR BELAKANG PENDIDIKAN CEO TERHADAP KINERJA KEUANGAN PERUSAHAAN GO PUBLIK YANG TERDAFTAR DI BURSA EFEK INDONESIA. Jurnal Akuntansi AKUNESA, 6(1), 1-20.

Kurnia, A. A., \& Anis, I. S. A. M. C. (2017). Analisis Fraud Pentagon dalam Mendeteksi Kecurangan Laporan Keuangan dengan Menggunakan Fraud Score Model.

Lestari, M. I., \& Henny, D. (2019). Pengaruh Fraud Pentagon Terhadap Fraudulent Financial Statements Pada Perusahaan Perbankan Yang Terdaftar Di Bursa Efek Indonesia Tahun 2015-2017. Jurnal Akuntansi Trisakti, 6(1), 141-156. https://doi.org/10.25105/jat.v6i1.5274 
Matangkin, L., Ng, S., \& Mardiana, A. (2018). Pengaruh Kemampuan Manajerial dan Koneksi Politik Terhadap Reaksi Investor Dengan Kecurangan Laporan Keuangan Sebagai Variabel Mediasi. SIMAK, 16, 182-209.

Ngan, S. C. (2013). The Impact Of Politically-connected Executives In Fraudulent Financial Reporting: Evidence Based On The H Shares. African Journal of Business Management, 7, 1875-1884.

Omar, N., Johari, Z. A., \& Smith, M. (2017). Predicting fraudulent financial reporting using artificial neural network. Journal of Financial Crime, 24(2), 362-387.

Pardoen, S. R. (1998). Assesment of Investment in Private Higher Education in Indonesia : The Case of Four Private Universities. Centre for Societal Development Studies Atma Jaya Catholic University.

Ratnasari, E., \& Solikhah, B. (2019). Analisis Kecurangan Laporan Keuangan: Pendekatan Fraud Pentagon Theory. 2(2), 98-112.

Sasongko, N., Nurmulina, A., \& Fernandez, D. (2019). Analysis of Fraud Factors in Financial Statement Fraud. The Journal of Social Sciences Research, 5(4), 918-923. https://doi.org/10.32861/jssr.54.918.923

Sasongko, N., \& Wijayantika, S. F. (2019). Faktor Resiko Fraud Terhadap Pelaksanaan Fraudulent Financial Reporting (Berdasarkan Pendekatan Crown'S Fraud Pentagon Theory). Riset Akuntansi Dan Keuangan Indonesia, 4(1), 67-76. https://doi.org/10.23917/reaksi.v4i1.7809

Sihombing, K. S., \& Rahardjo, S. N. (2014). Pengaruh Fraud Diamond dalam Mendeteksi Financial Statement Fraud (Studi Empiris pada Perusahaan Ritel yang Terdaftar di Bursa Efek Indonesia Tahun 2014 - 2016). Diponegoro Journal of Accounting, 3, 1-12.

Skousen, C. J., K. R. S., \& Wright, C. J. (2009). Detecting and Predecting Financial Statement Fraud: The Effectiveness of The Fraud Triangle and SAS No. 99.

Soselisa, R., \& Mukhlasin. (2008). Pengaruh Faktor Kultur Organisasi, Manajemen, Strategik, Keuangan, dan Auditor terhadap Kecenderungan Kecurangan Akuntansi: Studi Pada Perusahaan Publik di Indonesia. Simposium Nasional Akuntansi (SNA) Ke XI. https://doi.org/10.1017/CBO9781107415324.004

Sulkiyah. (2016). Pengaruh Ineffective monitoring Terhadap Financial Statement Fraud (Perusahaan Manufaktur yang Terdaftar di BEI). Journal Ilmiah Universitas Gunung Rinjani, 3, 129-140.

Triyanto, D. N. (2019). Fraudulence Financial Statements Analysis using Pentagon Fraud Approach. Journal of Accounting Auditing and Business, 2(2), 26. https://doi.org/10.24198/jaab.v2i2.22641

Troy, J. (2003a). Manajerial and Strategic Factor Leading to Accounting Fraud. SSRN. Troy, J. (2003b). Manajerial and Strategic Factor Leading to Accounting Fraud.

Vousinas, G. L. (2017). Advancing Theory of Fraud: The S.C.O.R.E Model. Journal of Financial Crime.

Wolfe, D. T., \& Hermanson, D. R. (2004). The Fraud Diamond: Considering the Four Elements of Fraud: Certified Public Accountant. The CPA Journal, 74(12), 38-42. https://doi.org/DOI:

Wu, W., Johan, S. A., \& Rui, O. M. (2014). Institutional Investors, Political Connections, and the Incidence of Regulatory Enforcement Against Corporate Fraud. Journal of Business Ethics, 134(4), 709-726.

Yang, D., Jiao, H., \& Buckland, R. (2017). The determinants of financial fraud in Chinese firms: Does corporate governance as an institutional innovation matter? Technological Forecasting and Social Change, 125, 309320. https://doi.org/10.1016/j.techfore.2017.06.035

Ying, C. H., \& Yeung, C. M. (2014). CEO Education and Firm Performance: Evidence From Hong Kong. Hong Kong Baptist University, 1. 